\author{
Andžèj Pukšto* \\ Vytauto Didžiojo universitetas
}

\title{
Lietuvos ir Lenkijos santykiai: naujos darbotvarkès paieškos
}

\begin{abstract}
Šio straipsnio tikslas yra išanalizuoti, kokios prielaidos yra sukurtos Lietuvos ir Lenkijos kultūriniam bendradarbiavimui, atskiriant tris dèmenis: dvišalị kultūrinį bendradarbiavimą, kultūrinę diplomatiją ir tautinių mažumų kultūrinę veiklą. Tokia atskirtis yra daroma sąmoningai, siekiant nustatyti Lietuvos ir Lenkijos santykị kaip subjekto ir objekto arba subjekto ir kito subjekto santykị tarp Lietuvos ir Lenkijos. Pirmuoju atveju, reikštų, kad Lietuva ir Lenkija yra viena kitos kultūrinès politikos objektas, antruoju, kad Lietuva ir Lenkija yra lygiavertès partnerès kultūrinio bendradarbiavimo srityje. Siekiant šio tikslo, būtina išanalizuoti ne tik dvišalę, bet ir nacionalinę teisinę bazę ir kultūrinę veiklą, nes kultūrine diplomatija yra skirta vienkrypčiam valstybès poveikiui kitai valstybei, o kultūrinis bendradarbiavimas apibrèžia bendro tikslo ịgyvendinimą kultūros srityje.
\end{abstract}

2015 metų rugpjūčio 6 dieną įvyko šeštojo Trečiosios Lenkijos Respublikos prezidento Andrzejaus Dudos inauguracija. Teisès ir teisingumo partijos atstovo pergalè prezidento rinkimuose buvo susieta su Jaroslawo Kaczynskio vadovaujamos partijos pergale parlamento rinkimuose. Visuomenès apklausos tik patvirtino šią sąsają: net 37 proc. piliečiu norètų, kad Lenkiją valdytų dešinieji, o ne senate ir seime dominuojanti centro „Piliečių platforma“ ${ }^{\text {"1. Po- }}$ litinès valdžios pasikeitimas Varšuvoje gali ir neturèti jokios teigiamos įtakos Lietuvos ir Lenkijos santykiams. Iૃtakingiausiuose Lenkijos savaitraščių Polityka, W sieci, Newsweek numeriuose, skirtuose pristatyti naujojo prezidento Andrzejaus Dudos politikos prioritetus, nè karto nebuvo paminèti santykiai su Lietuva. Pirmuosiuose interviu Duda taip pat neminèjo Lietuvos, o netrukus paaiškejo, kad pirmiesiems savo vizitams prezidentas pasirinko Taliną, o ne Vilnių.

Vyraujančios politinès tendencijos leidžia daryti kelias prielaidas. Visų pirma, Lietuvą ir Lenkiją vienijančiu interesu išliks saugumo užtikrinimas, o intensyvaus bendradarbiavimo sritimi - saugumo ir gynybos. Tačiau nepai-

\footnotetext{
${ }^{*}$ Dr. Andžè Pukšto - Vytauto Didžiojo universiteto Politologijos katedros vedèjas. Adresas korespondencijai: Gedimino g. 44-201, 44246 Kaunas, el. p. andzej.puksto@vdu.lt.

${ }^{1}$ Daugiau informacijos oficialiame 2015 metų Lenkijos parlamento rinkimų tinklapyje: http://ewybory.eu/ wybory-parlamentarne-2015/. 
sant to, kad kaimynės išliks Šaltojo karo su Rusija karèmis² ${ }^{2}$ būtina pabrèžti, kad Lenkijos elitas aukščiausiu prioritetu paskelbė Lenkijos suverenitetą ${ }^{3}$, kaip teisę spręsti, kas yra geriausia Lenkijos valstybei ir visuomenei. Iš to išplaukia, kad naujuose užsienio politikos prioritetuose Europos Sąunga taps erdve ne igalinančia igyvendinti juos, bet ribojančia pasirinkimą ir alternatyvius užsienio politikos sprendimo būdus. Skeptiškumas dèl ES priimamų sprendimų, neskiriamas deramas ES dėmesys Ukrainos krizei, didins Lenkijos poreikį ieškoti sąjungininkų Centrineje ir Rytų Europoje. Priimant regioninius sprendimus Varšuva ir Vilnius sugeba iškelti regioninius prioritetus aukščiau nacionalinių, tačiau dvišalių santykių kontekste pilnavertė strateginė partnerystė nebus atgaivinta tol, kol Lietuva neigyvendins savo ịsipareigojimų lenkų tautinei mažumai, ịtvirtintų Lietuvos Respublikos ir Lenkijos Respublikos draugiškų santykių ir gero kaimyninio bendradarbiavimo sutartyje. Vadinasi, Lietuvos ir Lenkijos santykiai vis dar niekur neveda ${ }^{4}$. Šiame kontekste būtina atkreipti dèmesi $\mathfrak{i}_{\text {t }}$ tas sritis, kuriose Lietuva ir Lenkija gali bendradarbiauti, nepaisant politikų nesugebejjimo palaikyti dialogą.

Kultūrinis bendradarbiavimas leidžia pažinti kitą visuomenę ir susitapatinti su ja: neigiamus stereotipus ilgainiui pakeičia teigiami, mažeja mes ir kiti mąstymo apraiškos tiek vidaus, tiek užsienio politikoje konkrečios valstybės atžvilgiu. Dèl šios priežasties kultūrinis bendradarbiavimas buvo skatinamas SSRS ir JAV Šaltojo karo laikotarpiu, nes kultūrinė diplomatija, kultūriniai kontaktai ir bendradarbiavimas kultūros srityje buvo laikomi galimybe pažinti priešiškas visuomenes, mažinti įtampą, keisti abipusius neigiamus stereotipus ir panaudojant kultūrinius mainus pakreipti kitos valstybès vidaus politiką sau parankia linkme $\mathrm{k}^{5}$. Lietuvos ir Lenkijos santykių kontekste kultūrinis bendradarbiavimas taip pat gali tapti viena alternatyvaus bendradarbiavimo sritimi, leidžiančia kurti strateginę partnerystę ne iš viršaus ị apačią, o iš apačios ị viršų.

Šio straipsnio tikslas yra išanalizuoti, kokios prielaidos sukurtos Lietuvos ir Lenkijos kultūriniam bendradarbiavimui, atskiriant tris dèmenis: dvišalị kultūrinį bendradarbiavimą, kultūrinę diplomatiją ir tautinių mažumų kultūrinę veiklą. Tokia atskirtis yra daroma sąmoningai, siekiant nustatyti Lietuvos

\footnotetext{
${ }^{2}$ Leonard, M., Popescu, N. A power audit of EU - Russia relations. European council on Foreign relations (ECFR), 2007, p. 2.

${ }^{3}$ Kaczyński, J. Mamy prawo bronić naszej suwerenności. Šaltinis: http://pis.org.pl/aktualnosci/mamyprawo-bronic-naszej-suwerennosci; žiūrèta: 20150917.

${ }^{4}$ Būtent taip apibūdino Lietuvos ir Lenkijos santykius tuo metu dar kandidatas ị Lenkijos prezidentus Andrzejus Duda. Šaltinis: http://kurierwilenski.lt/2015/05/29/polsko-litewskie-relacje-czeka-nowe-otwarcie/; žiūrèta: 20150602.

${ }^{5}$ Richmond, Y. Cultural Exchange and the Cold War: Raising the Iron Curtain. University Park: Pennsylvania State University Press, 2003, p. 210-211.
} 
ir Lenkijos santykị kaip subjekto ir objekto arba subjekto ir kito subjekto. Pirmuoju atveju reikštų, kad Lietuva ir Lenkija yra viena kitos kultūrinès politikos objektas, antruoju, kad Lietuva ir Lenkija yra lygiavertès partnerès kultūrinio bendradarbiavimo srityje. Siekiant šio tikslo būtina išanalizuoti ne tik dvišalę, bet ir nacionalinę teisinę bazę ir kultūrinę veiklą, nes kultūrinè diplomatija yra skirta vienkrypčiam valstybès poveikiui kitai valstybei, o kultūrinis bendradarbiavimas apibrèžia bendro tikslo iggvendinimą kultūros srityje ${ }^{6}$. Taigi, nors kultūrine diplomatija ir kultūrinis bendradarbiavimas yra glaudžiai susijusios sąvokos, jos negali būti vartojamos sinonimiškai: kultūrinè diplomatija yra vienos valstybės pastangos pristatyti savo kultūrą kitos valstybès visuomenei, o kultūrinis bendradarbiavimas apima bendras valstybių pastangas planuoti ir igyvendinti kultūros projektus. Pagrindinis klausimas, ị kurị siekiama atsakyti šiame straipsnyje, yra, ar Lietuva ir Lenkija bendradarbiauja kultūros srityje, ar yra viena kitos kultūrinès diplomatijos objektas. Dvišalis bendradarbiavimas suponuoja partnerystę ir lygiavertiškumą, o kultūrinè diplomatija nurodo sąmoningas valstybès pastangas paveikti kitos valstybès visuomenès nuomonę.

Kultūros politika yra viena sudètingiausių viešosios politikos sričių, neturinti bendros sampratos ${ }^{7}$, tačiau apibendrintai ši politika apima politinių ir administracinių sprendimų prièmimą ir igyvendinimą kultūros srityje (meninę ar kultūrinę vertę turinčių objektų kūryba, gamyba, pristatymas, platinimas ir išsaugojimas, švietimas, pramoginè veikla ir daugelis kitų procesų ir veiklự, pavyzdžiui, kalba, tradicijos, papročiai, religija). Taip pat kultūros politika ịtraukia ne valstybinès ar vietinès valdžios institucijas, bet ir kultūrines industrijas, mokymo ịstaigas, individus ar jų grupes. Taigi, kultūros politika yra ir prioritetu nustatymas, ir finansavimas, ir identiteto formavimas, ir paveldo išsaugojimas ${ }^{9}$. Valstybès kultūros politika turi dvi dimensijas: orientaciją $\mathfrak{i}$ vidaus veiklą ir orientaciją $\mathfrak{i}$ išorès veiklą. Orientacija ị išorès veiklą, arba užsienio kultūros politika, yra ne tik kultūrinès politikos, bet ir užsienio politikos sritis, kuri apima tiek tarptautinị bendradarbiavimą kultūros srityje (kultūros politika - pirmasis dėmuo), tiek kultūrinę diplomatiją (užsienio politika - antrasis dèmuo). Kodifikuota ir institucionalizuota valstybès kultūriné politika yra būtina sèkmingo tarptautinio kultūrinio bendradarbiavimo ir efektyvios kul-

\footnotetext{
${ }^{6}$ Daugiau informacijos apie kultūrinę diplomatiją ir kultūrinị bendradarbiavimą oficialiame Kultūrinès diplomatijos instituto tinklalapyje http://www.culturaldiplomacy.org/index.php?en_culturaldiplomacy. ${ }^{7}$ What is Cultural Policy? A Dialogue for an Emerging Field, Princeton University, Center for Arts and Cultural Policy Studies Faculty and Student Affiliates, 1999. Šaltinis: https://www.princeton.edu/culturalpolicy/dialgue.html; žiūrèta: 20150718.

${ }^{8}$ Mulchany, K. V. Cultural policy: Definitions and Theoretical approaches, The Journal of Arts Management, Law, and Society, Vol. 35, Is. 4, p. 319-330, 2006, p. 321.

${ }^{9}$ Lewis, J., Miller, T. Critical Cultural Policy Studies: A Reader, Oxford: Blackwell, 2003, p. 2-4.
} 
tūrinès diplomatijos sąlyga. Lietuvos ir Lenkijos dvišalių santykių kontekste nacionalinių kultūros politikų analizè parodo, kaip valstybės apibrěžia išorès kultūros politiką ir kokias priemones gali naudoti siekdamos ją igyvendinti. Šiame kontekste didžiausias dèmesys yra skiriamas nacionalinès kultūrinès politikos modelio pažangai, išorès (užsienio) kultūrinès politikos apibrěžimui, ịvertinimui, ar išorès politika yra skirta skatinti dvišali bendradarbiavimą kultūros srityje ar tiesiog naudoti kultūrą kaip švelniosios galios instrumentą vienai prieš kitą.

Pirminiai Lietuvos ir Lenkijos kultūrinès politikos tikslai sutapo - teisinès bazès, leisiančios vykdyti kultūrinę veiklą ir užtikrinti raiškos laisvę demokratijos ir rinkos ekonomikos sąlygomis, kūrimas. Pokomunistinėse valstybėse šis tikslas buvo igyvendinamas, siekiant kultūros politikos kompetenciją decentralizuoti: suteikti iggaliojimus šioje srityje veikti vietinès valdžios institucijoms. Taip pat buvo svarbu pritraukti visuomenės finansinę paramą kuriamoms ir esamoms kultūros institucijoms bei jų veiklai ir sukurti valstybinius kultūros finansavimo mechanizmus ${ }^{10}$. Ši procesą lydejo kultūrinių institucijų privatizavimas - privačių asmenų ir nevyriausybinių organizacijų įtraukimas $\mathfrak{i}$ kultūros sritị tapo ịprasta visose meno ir kultūros srityse ${ }^{11}$. Tokia pati tendencija vyravo ir Lenkijoje, ir Lietuvoje. Nepaisant to, reformų igyvendinimas Lenkijoje buvo sèkmingesnis ir tai lèmè Lietuvos ir Lenkijos kultūros politikos raidos etapų nesutapimą.

Lenkija sukūrẻ nacionalinès kultūros politikos modelị, kuriame išorès kultūros politika pabrèžia kultūrinès diplomatijos vaidmenį, o ne tarptautinio bendradarbiavimo. 1993 metais buvo patvirtinti Lenkijos kultūros politikos principai. 1998 metais imta kurti nauja Lenkijos kultūrinès politikos programa, ị kurios projektą pirmą kartą buvo įtrauktas toks prioritetas kaip Lenkijos kultūros sklaida užsienyje. Šis prioritetas tapo 1999 metais patvirtintos nacionalinès kultūros politikos tikslu, kurio iggyvendinimo funkcija buvo paskirta ne konkrečiai ministerijai, bet valstybei kaip institucijų visumai ${ }^{12}$. Šis procesas žymejjo poslinkị autonomijos ir strateginio planavimo kultūros srityje visais lygmenimis ${ }^{13}$. Svarbiausias pasiekimas šiuo laikotarpiu buvo kultūros politikos igyvendinimas ne tik ministerijų (kultūros ir nacionalinio paveldo ir užsienio reikalų), bet ir vietinès valdžios lygmeniu.

Ilgainiui buvo sukurta Nacionalinio kultūrinio vystymosi strategija

\footnotetext{
${ }^{10}$ Ibidem, p. 2.

${ }^{11}$ Liutkus, V. Country Report: Lithuania // "Compendium of Cultural Policies and Trends in Europe, 15th edition”, Council of Europe/ERICarts, 2014, p. 2.

${ }^{12}$ Ociepka, B. Miekka sila i dyplomacja publiczna Polski, Scholar: Warszawa, 2013, p. 149.

${ }^{13}$ Ilczuk, D., Novak, M., Pro Cultura Foundation, Culture and the Structural Funds in Poland, Paper, European Expert Network on Culture, 2012, p. 4-5.
} 
2004-2013 m., pratęsta iki 2020 metų. Pagrindinè šios strategijos idejja buvo galimybès išnaudoti ES fondus, išsaugant kultūrinị paveldą ir kultūrinį Lenkijos identitetą. Šios strategijos tarpiniu užsienio kultūros politikos pasiekimų ¿̇vertinimu tapo Lenkijos pirmininkavimas ES Tarybai 2012 metais. Kultūrinė pirmininkavimo programa parodè, kad dabartinis Lenkijos užsienio kultūrinés politikos modelis pasižymi keliomis svarbiausiomis savybėmis: orientacija ì Vakarų Europą, nutolimu nuo Rytų Europos; dvišalių projektų ir iniciatyvų pakeitimu ES institucijų projektai ir tiesioginio menininkų, jų tinklų, nevyriausybinių organizacijų ar institucijų bendradarbiavimo dominavimu ${ }^{14}$. Kultūrinis bendradarbiavimas tapo ne tik valstybès, bet ir privačių asmenų ar jų sukurtų institucijų atsakomybès sritimi nuo finansavimo iki kultūrinès diplomatijos igyvendinimo.

Lietuva tik praejus beveik dešimtmečiui nuo tada, kai Lenkija 1993 metais patvirtino Kultūros politikos principus, apibrèžè poreikị kurti nacionalinę kultūros vystymo programą ${ }^{15}$, tačiau šis tikslas taip ir liko neigyvendintas. 2001 metais buvo paskelbti Lietuvos kultūros politikos principai, kuriuose numatyta decentralizuoti ir demokratizuoti kultūros sritį, remiantis Europos tarnybos principais - demokratiško sprendimų prièmimo, skaidrumo, teisès viršenybės.

2010 metais kritiška padètis kultūros srityje buvo įvertinta ir sukurtos Kultūros politikos kaitos gairès, kuriose buvo pripažinta, kad kultūros sritis išliko menkai decentralizuota, finansavimas šiai sričiai yra nepakankamas, o ir apskritai kultūra taip ir nebuvo laikoma strategine Lietuvos raidos krypti$\mathrm{mi}^{16}$. Taigi, būtina kultūros srities transformacija, paremta Europos Tarybos principais, pradèta igyvendinti, kai Lietuva jau šešerius metus buvo ES nare. Demokratizacija, decentralizacijos ir finansinès autonomijos ir diversifikacijos procesai vis dar išlieka Lietuvos prioritetu Kultūros srityje. Lietuvos kultūrinès politikos modelis yra tik kuriamas ir tai lemia kokybinị atotrūkị nuo Lenkijos kultūros politikos modelio raidos ir kultūrinès diplomatijos iggyvendinimo galimybių.

Nuo 2009 metų kultūra Lenkijos užsienio politikoje yra traktuojama kaip švelniosios galios pagrindas ${ }^{17}$ - Lenkijos populiarinimo kryptyse iki 2015 metų ir Lenkijos užsienio politikos prioritetuose 2012-2016 m. yra įtvirtinta nuostata, kad Lenkų kultūros sklaida užsienyje ir kultūros diplomatija yra vienas iš svarbiausių būdų sustiprinti Lenkijos poziciją Europoje, skatinti turizmą

\footnotetext{
${ }^{14}$ Ilczuk, D., Pro Cultura Foundation collaborators, Country report: Poland // "Compendium of Cultural Policies and Trends in Europe, 15th edition", Council of Europe/ERICarts, 2014, p. 9.

${ }^{15}$ II, III principai. Lietuvos kultūros politikos principai, Nr. 542, Vilnius, 2001.

${ }^{16} 1$ gairè. Lietuvos kultūros politikos kaitos gairès, Nr. XI-977, Vilnius, 2010.

${ }^{17}$ Ociepka, B. Opt. cit., p. 152.
} 
ir netgi užsienio investicijas. Be to, dar 2013 metais patvirtinta prekès ženklo Lenkija komunikacijos taisyklès. Svarbiausias vaidmuo ịgyvendinant Lenkijos kultūros politiką tenka Lenkijos institutams, kurių tikslas yra platinti žinias apie Lenkiją ir užtikrinti lenkų dalyvavimą tų šalių, kuriose gyvena, kultūros gyvenime. Būtent šiam tikslui pasiekti veiksmingiausia priemone yra laikoma bendri projektai su vietinėmis žinomomis kultūros institucijomis. Lenkija aktyviai siekia pakeisti tų valstybių, kuriose veikia Lenkijos institutas, visuomenių ir svarbių atskirų jos narių nuomonę í palankią Lenkijos iggyvendinamai vidaus ir užsienio politikai, mažinant neigiamus stereotipus ir formuojant grupes, išimtinai palankias Lenkijai: „formuojamos būsimų sąjungininkų - Lenkijos pažinimo, polonistikos, slavistikos fakultetų ir Vidurio Europos studijų darbuotojų ir studentų - gretos garsinant lenkų laimèjimus. "18 Taigi, Lenkija aktyviai populiarina savo kultūrą ir tuo pačiu metu siekia sukurti sistemingą, palankų valstybès ịvaizdį tarptautinèje erdveje. Lenkijos kultūrinè diplomatija ir kultūrinis politikos modelis akivaizdžiai lenkia lietuviškajị.

Lietuva tik 2010 metais èmè formuoti kultūros sklaidos užsienyje, tarptautinio bendradarbiavimo kultūros srityje programas bei ES Struktūrinių fondų paramos perspektyvą ${ }^{19}$. Lietuvos užsienio kultūros politika yra grindžiama dvišalių kultūrinių susitarimų ir programų igyvendinimu, tačiau pirmininkavimas ES Tarybai 2013 metais paskatino orientuotis ị kultūrinio identiteto išsaugojimą ir jo reprezentavimą Europinejje erdveje, neapsiribojant Šiaurès Europa ${ }^{20}$. Pasiruošimas pirmininkauti Kultūros programos igyvendinimui paskatino Tarptautinio kultūros programų centro (K-operator) sukūrimą 2008 metais. Taigi, Lietuvos kultūros politika vis dar nukreipta ị valstybės vidų, siekiant populiarinti Lietuvos kultūrą tarp lietuvių, gyvenančių Lietuvoje ir užsienyje $\mathrm{e}^{21}$ : meno kūrybos ir kultūrinių industrijų stoka išlieka daug didesne problema nei minimalus tarptautinis kultūrinis bendradarbiavimas nacionaliniu lygmeniu. Lietuvos kultūros politika yra nukreipta, visų pirma, ị paveldo išsaugojimą, kultūrinio identiteto ribų nustatymą ir ịtvirtinimą. Geriausias šio prioriteto ịgyvendinimo pavyzdys yra Lietuvos kultūros instituto įsteigimas 2009 metais.

Apibendrinant Lietuvos ir Lenkijos kultūros politiką galima daryti kelias išvadas. Visų pirma, Lenkija sukūrẻ kompleksinị kultūros politikos modelị, o Lietuva modelị dar tik kuria. Antra, Lenkijos modelyje yra aiškiai

\footnotetext{
${ }^{18}$ Lenkų insitutas Vilniuje. Šaltinis: www.lenkukultura.lt.

${ }^{19}$ 10, 11 gairès. Lietuvos kultūros politikos kaitos gairès, Nr. XI-977, Vilnius, 2010.

${ }^{20}$ Liutkus, V. Country Report: Lithuania // "Compendium of Cultural Policies and Trends in Europe, 15th edition”, Council of Europe/ERICarts, 2014, p. 11-12.

${ }^{21}$ Tikslai ir programos. Lietuvos Respublikos kultūros ministerijos 2015-2017 metų strateginis veiklos planas, Nr. İV-37, Vilnius, 2015.
} 
suformuoti vidaus ir išorès / užsienio kultūros politikos prioritetai ir tikslai. Lietuvos išorès kultūros politika yra kuriama ad hoc. Trečia, Lenkijos kultūrinès politikos modelis pabrèžia išorès dimensiją, Lietuvos kultūrinè politika yra orientuota $\mathfrak{i}$ valstybės vidų. Ketvirta, Lenkijos vidaus kultūros politika yra priskiriama individų veiklos sričiai, išorès politika - valstybès institucijų. Lietuvoje valstybės institucijos daugiau veikia vidaus politikos srityje, tačiau dominuojantis vaidmuo tiek vidaus, tiek išorès politikoje tenka individams ar jų grupèms, nevyriausybinèms organizacijoms. Penkta, išorès kultūros politikoje Lenkija skatina kultūrinę diplomatiją, o ne kultūrinị bendradarbiavimą. Lietuva užsienio kultūros politikoje pabrèžia tarptautinio bendradarbiavimo naudą, o kultūrinė diplomatija nèra laikoma prioritetine ar strategine veiklos sritimi nei kultūros, nei užsienio politikoje. Taigi, Lenkija kultūros srityje kitų valstybių atžvilgiu propaguoja subjekto ir objekto santykị, o Lietuva ribotai skatina dviejų subjektų santykį. Pažangesnès Lenkijos užsienio kultūros politikos modelis atsispindi Lietuvos ir Lenkijos dvišalio bendradarbiavimo kultūros srityje teisiniame reglamentavime.

Lietuvos ir Lenkijos sutartis dèl draugiškų santykių ir gero kaimyninio bendradarbiavimo įtvirtino labai ribotą kultūros, kultūrinès raidos ir bendradarbiavimo interpretaciją. Nacionalinès kultūros stiprinimas ir jos plètra buvo tiesiogiai susieta su nacionaliniu Lenkijos ir Lietuvos saugumu ir atsparumu išorès grèsmėms nestabilioje pilkojoje saugumo zonoje iki narystès NATO. Šis kaimynių požiūris lèmè maksimaliai ribotą kultūrinị bendradarbiavimą, todèl dvišalių santykių kontekste buvo pabrèžiama saugumo, gynybos ir ekonominio bendradarbiavimo darbotvarkè. Be to, tautinès mažumos buvo laikomos objektu, kurị reikia saugoti nuo kaimyninès valstybès vidaus politikos net ir kultūros srityje ${ }^{22}$. Kultūrine ir kalbine tautinių mažumų integracija ị šias visuomenes buvo siekiama sukurti homogeniškos, vieningos valstybės ịvaizdị, nes politinis stabilumas ir ekonominis vystymasis garantavo valstybingumo itvirtinimą.

1996 metais Lietuva ir Lenkija pasiraše teritorinès sienos sutartị, kuri užbaigė konfliktiškų Lietuvos ir Lenkijos santykių periodą. Didžiausią ịtaką tam turëjo Lenkijos stojimo į NATO procesas: Lenkija neabejotinai turèjo tapti NATO nare per artimiausius kelerius metus, o Lietuvai NATO jokiu konkrečiu ịsipareigojimų nebuvo įvardijusi. Taigi, Lenkijos narystė NATO ne tik buvo tiesiogiai susijusi su Lietuvos nacionaliniu saugumu dẻl priklausymo vienam saugumo kompleksui, bet ir dèl potencialios Lenkijos kaip NATO na-

\footnotetext{
${ }^{22}$ Draugiškų santykių ir gero kaimyninio bendradarbiavimo sutartis, Valstybès žinios, 1994-12-16, Nr. 97-1907, Vilnius, 1994. Str. 13-17.
} 
rès palaikymo Lietuvos narystei ir dèl pagalbos pasirengti atitikti šios narystės keliamus reikalavimus ${ }^{23}$. Dèl šios priežasties po teritorinių sienų įtvirtinimo sutarties pasirašymo Lietuvos Prezidentas Algirdas Brazauskas ir Lenkijos Prezidentas Aleksandras Kvašnevskis pasirašè bendrą deklaraciją, kurioje teigiama, kad Lietuva ir Lenkija rems „,viena kitą integracijos ị Europos Sąjungą, Vakarų Europos sąjungą ir NATO procesuose“, taip pat sieks „suintensyvinti bendradarbiavimą visose srityse, ypač užsienio ir saugumo politikos, gynybos, ekonomikos, prekybos, transporto ir komunikacijų, infrastruktūros, kultūros

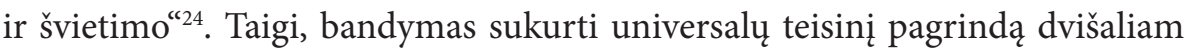
kultūriniam Vilniaus ir Varšuvos bendradarbiavimui buvo siekis užsitikrinti nacionalinị saugumą ir tapti NATO naremis.

Iki 1998 metų Lietuva ir Lenkija neteikè didelès reikšmès bendradarbiavimo kultūros srityje skatinimui nacionaliniu lygmeniu. Draugiškų santykių ir geros kaimynystès sutartyje nebuvo pabrèžiama būtinybẻ skatinti kultūrini bendradarbiavimą, kuris leistų pažinti kitos valstybès kultūrą ir taip gilinti tarpusavio supratimą. Sutarties, kaip ir 1993 metų prezidentų deklaracijos, tekstas suteike prielaidas tik kultūrinès diplomatijos viena kitos atžvilgiu plètojimui: kultūros populiarinimo institucijų steigimas, galimybès mokytis kaimyninès valstybès kalbą, skatinti lituanistines ir polonistines studijas ${ }^{25}$. Taigi, teisinis Lietuvos ir Lenkijos bendradarbiavimo pagrindas nebuvo paskata efektyviam kultūriniam bendradarbiavimui, kurio tikslas yra skatinti taiką, tarpusavio supratimą ir praturtinti bendradarbiaujančių šalių kultūrą ${ }^{26}$. Reglamentuotas bendradarbiavimas kultūros srityje buvo traktuojamas kaip legitimus būdas vystyti kultūrinę diplomatiją - sukurti prielaidas igyvendinti nacionalinius tikslus, pakeitus kitos valstybès viešąją nuomonę ${ }^{27}$. Dèl šių nuostatų atsirado Lenkijos institutas Vilniuje 1995 metais ir veikia iki šiol.

Plačiai taikomos Vidurio ir Rytų Europoje Geros kaimynystès ir draugiškų santykių sutartys kultūrinį bendradarbiavimą apibrěže kaip abipusị bendro ir nacionalinio kultūrinio paveldo išsaugojimą, tačiau nebuvo orientuotos ì bendrų kultūrinių projektų ịgyvendinimą dèl didelių vidinių reformų būti-

\footnotetext{
${ }^{23}$ Sirutavičius, V. Lithuanian-Polish Strategic Partnership: Genesis and Prospects. Lithuanian Political Science Yearbook, Issue 1, 2000, p. 2-3.

${ }^{24}$ Lietuvos Respublikos Prezidento ir Lenkijos Respublikos Prezidento bendra deklaracija, Gdynia, 19960916.

${ }^{25}$ Draugišku santykiu ir gero kaimyninio bendradarbiavimo sutartis, Valstybès žinios, 1994-12-16, Nr. 97-1907, Vilnius, 1994. Str. 20.

${ }^{26}$ Declaration of Principles of International Cultural Co-operation, General Conference of UNESCO, XIVth Session, Paris, 1966. Str. 4, 6.

${ }^{27}$ Schneider, C. P. Culture Communicates: US Diplomacy That Works // Melissen, J. (ed.) The new Public Diplomacy: Soft Power in International relations. Basingstoke: Palgrave Macmillian, 2005, p. 147.
} 
nybės. Pažadas plètoti bendradarbiavimą kultūros srityje imtas igyvendinti tik po Lenkijos įstojimo į NATO. Vyriausybių sutartis dèl bendradarbiavimo kultūros, švietimo ir mokslo srityje buvo pasirašyta 1998 metais, tačiau nepaisant labai aptakaus sutarties teksto, skirto „geresniam abiejų valstybių piliečių

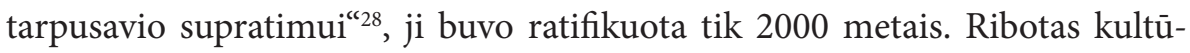
rinio bendradarbiavimo reglamentavimas buvo nulemtas kultūrinès politikos modelio kūrimo tiek Lenkijoje, tiek Lietuvoje. Be visavertès nacionalinès kultūros programos ir jos ịgyvendinimo nebuvo įmanoma plettoti efektyvų kultūrinị bendradarbiavimą, tačiau kaip kitose dvišalio bendradarbiavimo srityse svarbiausią vaidmenį atliko kultūrinès politikos prioritetų ir tikslų sutapimas. Dèl šios priežasties devintasis dešimtmetis buvo skirtas Lietuvos ir Lenkijos vidaus politikos procesams - kultūriniam regionų vystymuisi, bet ne aktyviam kultūriniam bendradarbiavimui. Taigi, teisinis dvišalio kultūrinio bendradarbiavimo reglamentavimas yra ribotas ir neịpareigojantis, o Draugiškų santykių ir geros kaimynystès sutartytis pabrěžia ne kultūrinị bendradarbiavimą, bet kultūrinès diplomatijos ịgyvendinimą.

Kultūrinis Lietuvos ir Lenkijos bendradarbiavimas yra ne nacionalinès programos, bet būtent regionų ir vietinès valdžios bei bendruomenių ar atskirų individų prioritetas dèl dviejų priežasčių: Lenkijos vidaus kultūros poltika yra priskiriama individų veiklos sričiai, išorès politika tenka valstybės institucijų kompetencijai, bet kadangi išorès kultūros politikoje Lenkija skatina kultūrinę diplomatiją, bet ne kultūrinị bendradarbiavimą, o Lietuva užsienio kultūros politikoje pabrežia tarptautinio bendradarbiavimo naudą, tačiau kultūros sritis Lietuvos atveju yra individų, o ne valstybès veiklos sritis, tai iš to išplaukia, kad dvišaliu valstybiniu lygmeniu kultūrinis Lietuvos ir Lenkijos bendradarbiavimas yra nerezultatyvus, o pati bendradarbiavimo iniciatyva ar jų igyvendinimas tiesiogiai priklauso nuo asmeninių ar grupinių Lietuvos ir Lenkijos piliečiu iniciatyvu. Puikiausias to ịrodymas Jerzy Giedroyco dialogo ir bendradarbiavimo forumas ir Lenkijos ir Lietuvos draugystès ir bendradarbiavimo forumas, ịkurtas 2012 metais, siejantis Lietuvos ir Lenkijos mokslininkus, politikos, kultūros, meno, žiniasklaidos atstovus, intelektualus, visuomeninių organizacijų atstovus, skatinant bendradarbiavimą meno, kultūros, mokslo, švietimo srityse, jaunimo mainus, istorinius ir visuomeninius debatus. Šie forumai, rodantys didžiausius kultūrinio bendradarbiavimo rezultus, buvo visuomenès atstovų asmeninė iniciatyva - menininkų, mokslininkų, visuomenès veikèjų.

\footnotetext{
${ }^{28}$ Preambulè. Lietuvos Respublikos Vyriausybès ir Lenkijos Respublikos Vyriausybès sutartis dèl bendradarbiavimo kultūros, švietimo ir mokslo srityje, Valstybès žinios, 2000-04-07, Nr. 29-809, Vilnius, 19981217.
} 
Lietuvos ir Lenkijos institucijų ribotą susidomëjimą kultūriniu bendradarbiavimu nacionaliniu lygmeniu rodo demesys tik paveldosaugos, profesinių, mokslinių, edukacinių mainų klausimams, pavyzdžiui, tarp Vavelio rūmų ir LDK valdovų rūmų, Lietuvos dailès muziejaus ir Nacionalinio muziejaus Varšuvoje. Tačiau Lietuvos ir Lenkijos jaunimo mainai, muziejininkų profesiniai mainai ar bibliotekų ir archyvų keitimasis medžiaga nèra pakankamas intensyvaus kultūrinio bendradarbiavimo rodiklis. Nacionaliniu lygmeniu didžiausiu pasiekimu yra laikoma tai, kad Lietuvos Seimo ir Lenkijos Senato sprendimai 2011-uosius paskelbti Nobelio literatūros premijos laureato Č. Milošo metais, minint 100-ąsias gimimo metines. Nepaisant to, renginiai vyko paraleliai Lietuvoje ir Lenkijoje, o bendrų projektų buvo ịgyvendinta vos keletas $^{29}$. Taigi, nei kaimynystè, nei bendra tautu istorija nèra veiksnys, skatinantis efektyvų kultūrinį bendradarbiavimą valstybiniu lygmeniu, todèl kad Lietuva ir Lenkija orientuojasi ị skirtingas kultūrinès veiklos erdves. Sèkmingiausiu ir bene vieninteliu regioninio Lietuvos ir Lenkijos kultūrinio bendradarbiavimo pavyzdžiu galima laikyti „Paribio“ fondo veiklą. Seiniuose įkurtas fondas ir centras „Paribys - menų, kultūrų, tautų“ yra lenkų nevyriausybinè privati organizacija, pradejusi veikti dar 1990 metais. Nuo 2000 metų Kèdainių krašto muziejus èmé dalyvauti fondo projektuose: „Stiklo karoliukų žaidimas“ ir „Paribio Atlantida - valstybių sienas kertantis kultūrinis kelias“. Taigi, bendradarbiavimas kultūros srityje nèra aktyvus, nepaisant bendros teritorinès sienos ir ilgametès dviejų tautų bendros istorijos.

Nepaisant Lietuvos ir Lenkijos priklausomybès Baltijos jūros regionui, Lietuva po nepriklausomybès atkūrimo didžiausią dėmesį skyrẻ bendradarbiavimui su Baltijos šalimis - Latvija ir Estija - ir Šiaurès Europos valstybėmis. Lietuva apibrèžia savo kultūrinị bendradarbiavimą dvišaliu formatu daug dažniau nei daugiašaliu dèl to, kad Lietuvos geografinè kultūrinio bendradarbiavimo kryptis yra Europos ekonomine erdvé, apimanti ne tik ES, bet ir Skandinavijos valstybes. Nuo 2012 metų Lietuva, Latvija ir Estija pradèjo kultūrinio bendradarbiavimo ir kultūrinès veiklos koordinavimo strateginị planavimą ${ }^{30}$. Taigi, būtent Skandinavijos ir Baltijos šalys buvo ir išlieka Lietuvos užsienio kultūros politikos prioritetine sritimi - Šiaurès ministrų taryba ${ }^{31}$ ir Ars Balti$\mathrm{ca}^{32}$ yra svarbiausia Lietuvos tarptautinio kultūrinio bendradarbiavimo erdvè. Svarbu paminèti ir tai, kad Lietuvos bendradarbiavimas per sieną kultūros srityje taip pat intensyviausiai plètojamas su Skandinavijos ir Baltijos valsty-

\footnotetext{
${ }^{29}$ Tarptautinė programa „Milošo kelias“. Šaltinis: http://www.llti.lt/failai/Miloso\%20programa.pdf.

${ }^{30}$ Tarpministerinès kultūrinio bendradarbiavimo programos 2012-2014; 2014-2016 m.

${ }^{31}$ Šiaurès ministrų tarybos biuras Lietuvoje. Šaltinis: http://www.norden.lt/projektai/8.

${ }^{32}$ Ars Baltica. Šaltinis: http://www.ars-baltica.net/projects/projects.html.
} 
bėmis: Baltijos Euroregiono tinklas yra puikiausias tokio bendradarbiavimo pavyzdys, pradètas dar 2006 metais. Taip pat Lenkija visada pabrèžè savo europinį identitetą, o nuo 2004 metų ėmé siekti būti tiltu tarp Vakarų ir Rytų Europos. Dèl šios priežasties Lenkijos užsienio kultūros politika ir kultūrinè diplomatija yra orientuota $\mathfrak{i}$ ES branduolio valstybes (Vokietiją, Prancūziją ir Didžiąją Britaniją) ir ES Rytų partnerystės valstybes, teikiant ypatingą dèmesį Ukrainai.

Rengiamos parodos, bendri kūrybiniai projektai, kino filmų kūrimas, festivaliai ar kultūros dienos yra ne dvišalès Lietuvos ir Lenkijos darbotvarkès pasiekimai. Nacionaliniu lygmeniu Lenkija Lietuvos atžvilgiu igyvendina kultūrinę diplomatiją, o kutūrinis bendradarbiavimas yra vietinès valdžios ir individų motyvacijos ir veiklos nuopelnas, pavyzdžiui, Gdansko dienos Vilniuje, Vilniaus dienos Gdanske, Lietuvos kultūros dienos Krokuvoje. Netgi labiausiai prisidejję prie Lietuvos ir Lenkijos santykių puoselëjimo asmenys ar institucijos yra dažniau ịvertinami Jerzy Giedroyco dialogo ir bendradarbiavimo forumo, o ne valstybinių Lietuvos ar Lenkijos institucijų.

Kultūrinè valstybès raida ir kultūrinès politikos kūrimas po Šaltojo karo pabaigos nei Lietuvai, nei Lenkijai nebuvo prioritetas. Devintasis dešimtmetis buvo skirtas valstybių politinei ir ekonominei transformacijai: demokratijos konsolidacija ir rinkos ekonomikos kūrimas tapo valstybių vidaus politikos varomąja jèga. Šie vidiniai procesai taip pat užtikrino galimybę igyvendinti užsienio politikos tikslą - narystė ES ir NATO. Nacionalinis saugumas buvo pirminis valstybių nacionalinis interesas, lèmęs visų sričių raidą. Istorinė patirtis reikalavo Lietuvos ir Lenkijos nesaugumą sumažinti šliejimusi prie JAV ir naryste tarptautiniuose demokratiškuose forumuose, kurie garantuoja visoms, net ir silpnoms valstybėms, lygiaverčio balso teisę.

Didžiausią ịtaką kultūrinei Lenkijos ir Lietuvos politikai iki 2004 metų turejjo šių valstybių priklausymas Europos Tarybai - tarptautiniam forumui, skirtam siekti didesnès jos narių vienybès, kad būtų apsaugoti ir igyvendinti idealai ir principai, kurie yra bendras jų paveldas, ir skatinama jų ekonominé ir socialinè pažanga ${ }^{33}$. Priklausymas Tarybai reikalavo decentralizuoti ir demokratizuoti visas nacionalinès politikos sritis, ịskaitant ir kultūros politiką. Dabartinio nacionalinio kultūros modelio kūrimą ir jo tikslų igyvendinimą labiausiai veikia Lietuvos ir Lenkijos narystė ES, nes ES teikia paramą kultūros projektams iš Struktūrinių fondų ar Sanglaudos programos lèšų.

Kultūrinis Lietuvos ir Lenkijos bendradarbiavimas yra ne nacionalinès programos, bet vietinès valdžios ir bendruomenių ar atskirų individų priorite-

${ }^{33} 1$ straipsnis. Europos Tarybos tikslas. Europos Tarybos statutas, Londonas, 1949. 
tas. Ši tendencija yra nepakankamai kultūrai skiriamo finansavimo ir strateginio planavimo rezultatas. Lenkija orientuojasi ị kultūrinès diplomatijos teikiamą naudą ir sistemingą valstybès ịvaizdžio kūrimą. Lietuva vis dar iggyvendina būtinas reformas kultūros srities administravimo, kultūrinių industrijų kūrimo, kultūros decentralizacijos ir kitose srityse.

Didžiausia kliūtis kultūriniam Lietuvos ir Lenkijos bendradarbiavimui yra skirtingi valstybių kultūrinės politikos raidos etapai, prioritetai ir geografinẻ kultūrinio bendradarbiavimo kryptis. Tenka pripažinti, kad Lietuvos sugebejjimą igyvendinti kultūros diplomatiją ir palaikyti intensyvų kultūrinị bendradarbiavimą nacionaliniu lygmeniu lemia ir kompetentingų, tik šiai misijai sukurtų institucijų stygius. Lietuva ir Lenkija tik kuria sąlygas nacionalinių kultūros politikų, atitinkančių ES ir Europos Tarybos standartus, iggyvendinimui, todèl kultūrinis bendradarbiavimas nèra laikomas prioritetu, o sẻkmingi kultūrinio Lietuvos ir Lenkijos bendradarbiavimo rezultatai yra veikiau išimtis, o ne taisyklè. 